\title{
A közúti ellenörzés pszichikai hatása és a szabályszegő magatartások háttere ${ }^{1}$
}

\section{JUHÁSZ Anikó ${ }^{\oplus}$ - MAJOR Róbert ${ }^{3 \oplus}$}

\begin{abstract}
A biztonságos közlekedés alapfeltétele a szabálykövető magatartás. Az egyén szabálykövetö magatartásához viszont nélkülözhetetlen annak belátása, hogy a közlekedésre vonatkozó szabályrendszer léte szükségszerü. A társadalom sikeres együttmúködéséhez és a demokratikus rend fenntartásához elengedhetetlenek az elfogadott normák, szokások, erkölcsi minták, szerepek, etikai szabályok, viselkedési minták és az együttélést segítő magatartásformák. A szabályokhoz, jogszabályokhoz való viszonyulást jelentős mértékben befolyásolják olyan személyiséget meghatározó jellemzők, mint például a büntetésre adott reakciók, a büntetés emberre gyakorolt rövid és hosszú távú hatása. A szabályszegő vagy szabálykövető magatartás elkülönítésében szerepet játszik a nemi különbségeken túl az agresszió, a kockázatvállalás, az önkontroll és a társas felelösségtudat mértéke. Az emberek abban is eltérnek egymástól, hogy milyen fokú kontrollt képesek gyakorolni érzelmeik felett. A különböző erkölcsi fejlődésszint maga után vonja a közlekedésben tanúsított változó viselkedésformákat, akár a devianciát is. A helyes attitüd számos szociális kompetenciát magában foglal, a toleráns magatartás gyakorlása mellett. A jogsértés elkerüléséhez nélkülözhetetlen az önszabályozás, az autonómia, az együttmúködés és a problémakezelés képességének birtoklása. A szabályok betartásának növelése érdekében csökkenteni kell a szabályos magatartás hátrányos és növelni az elönyös következményeinek valószínűségét. A megelőző rendőri fellépéssel kapcsolatos intézkedések a közúti biztonság növelésére, a balesetek előfordulásának megelözésére irányulnak. A cél, hogy a közúti közlekedés minden résztvevője maradéktalanul tiszteletben tartsa a szabályokat. Jelen tanulmány azt járja körbe, hogy valójában miért van szükség a közlekedési szabályok betartásához való helyes hozzáállásra, milyen emberi tényezőkkel magyarázható a közlekedésbiztonsági kockázatot jelentő szabályszegés, és a büntetés miképp hat az eltérő személyiségjegyekkel rendelkező gépjármúvezetőkre a szituáció függvényében.
\end{abstract}

Kulcsszavak: közlekedéspszichológia, baleset-megelőzés, közúti ellenőrzés, közlekedésbiztonság, szabályszegés

A tanulmány az Innovációs és Technológiai Minisztérium ÚNKP-20-3-II-NKE-110 kódszámú Új Nemzeti Kiválóság Programjának szakmai támogatásával készült.

2 Juhász Anikó, pszichológus, gyógypedagógus, Nemzeti Közszolgálati Egyetem Rendészettudományi Doktori Iskola, doktori hallgató.

Anikó Juhász, Psychologist, Special Education Teacher, University of Public Service Doctoral School of Law Enforcement, PhD student. E-mail: juhasz.aniko@uni-nke.hu

3 Dr. Major Róbert, rendőr ezredes, NKE Rendészettudományi Kar Közbiztonsági Tanszék, egyetemi docens.

Róbert Major Police Colonel, University of Public Service, Department of Public Safety, Faculty of Law Enforcement, Associate Professor. E-mail: major.robert@uni-nke.hu 


\section{Hatósági ellenőrzés}

A közvélemény számára a rendőrség közlekedésrendészeti tevékenysége túlnyomórészt a közúti ellenőrzésben megnyilvánuló kellemetlenkedésben jelenik meg. Különösen a sebességellenőrzés kapcsán hallhatók - néha igen erőteljes - hangok, amelyek azt a nézetet sugallják, hogy a rendőri forgalom-, illetve sebességellenőrzés csupán az állami bevételek, a sokszor emlegetett adóbevételek egyik forrása, semmi más értelme nincsen. Ezzel párhuzamosan folyamatosan a közlekedési morál hiányáról, az elégtelen kooperációról, illetőleg a tolerancia és az udvariasság, előzékenység teljes hiányáról beszélnek.

A közlekedésben megjelenő hatósági ellenőrzés valójában a rendőrség közlekedésrendészeti tevékenységének jól érzékelhető megjelenési formája.

„A közlekedésrendészet a biztonságos, balesetmentes, a személy- és vagyonbiztonság sérelmét elkerülő közlekedés állami, adminisztratív igazgatási tevékenységgel való biztosítása, melyhez - mint minden rendészeti tevékenységhez - kapcsolódik, a kikényszeríthetőség, amihez akár erőszak alkalmazása is társulhat." ${ }^{\text {" }}$

A közlekedésrendészet - fenti cél biztosítására szolgáló - alapfeladatai a közlekedési hatósági és rendészeti feladatellátás, a közlekedési feltételek figyelemmel kísérése, a közlekedésbiztonság felügyelete és fenntartása.

A közlekedésbiztonság megteremtése azonban nem tekinthető csupán állami feladatnak, össztársadalmi feladatról van szó, amely az egyes állami és önkormányzati szervek és az állampolgárok együttmúködésével valósítható meg. Az ilyen együttmúködéssel kialakított közlekedésbiztonság védelmezhető rendészeti eszközökkel, a rendet elfogadó közlekedési résztvevők védelme érdekében, a normasértô magatartást tanúsítókkal szemben.

E rendészeti feladat nyilvánul meg a közlekedés kontroll alatt tartásában. A közúti közlekedés ellenőrzése során a kontroll kiterjed a közlekedés rendjének és a forgalomszabályozásnak, továbbá a közlekedési szolgáltatásnak és a jármüvek üzemeltetésének szabályszerűségére.

A forgalom ellenőrzésének legfontosabb alapelvei: ${ }^{5}$

- A kontrollt a baleseti okokként megjelölt szabályszegésekre kell fókuszálni, szakítva az általános szúrópróbaszerű ellenőrzési gyakorlattal.

- A kontrollt ki kell terjeszteni az úgynevezett „irritáló” szabályszegő magatartások kiszűrésére.

- A kontrollt erősíteni kell a passzív biztonsági eszközök használatának tekintetében.

\footnotetext{
Major Róbert: Rendészet, közlekedésrendészet. In Barabás A. Tünde (szerk.): Tanulmányok Irk Ferenc professzor 70. születésnapjára. Budapest, Országos Kriminológiai Intézet, 2012. 191-210.

5 Major Róbert: A közlekedésrendészet. In Korinek László (szerk.): Értekezések a rendészetről. Budapest, Nemzeti Közszolgálati Egyetem, 2014. 227-252.
} 
- A kontroll során nevelő célzatú tájékoztatást kell adni.

- Tudatosítani kell a jármúvezetőkben, hogy bárhol és bármikor ellenőrzés alá kerülhetnek.

A 20. század második feléig a bűnmegelőzést kizárólag rendészeti eszközökkel végrehajtható tevékenységként kezelték, a biztonság megteremtését és a bünözés elleni küzdelem folytatását kizárólagosan rendőri feladatnak tekintették. ${ }^{6}$ A rendészeti eszközök „tehetetlensége” a kutatók figyelmét a kriminológia más eszköztára felé irányította. Előtérbe kerültek a bűnmegelőzés jogon kívüli eszközei. Olyan egyszerű intézkedésekre kell gondolni, mint például a gyermekektől való mobiltelefon elrablásának megelőzése érdekében a nyakban hordott telefont a ruházat alá kell tenni, vagy a lakótelepi zöld övezetekben az épített környezetet és a növényzetet úgy kell kialakítani, hogy szemmagasságban nagy terület átlátható legyen. A szituációs bűnmegelőzés nem más, mint azon bűnalkalom-csökkentő intézkedések összessége, amelyek speciális bűncselekményformákra irányulnak, és a közvetlen környezet szisztematikus és strukturális változtatását jelentik annak érdekében, hogy a bűncselekmény elkövetését kockázatosabbá, nehezebben megvalósíthatóvá tegyék, és ezáltal csökkentsék az elkövető hasznát. ${ }^{7}$ A racionális választás elmélete tulajdonképpen a bűnelkövető költség-haszon elemzésén alapszik: ha túl nagy a lebukás és a büntetés kockázata a cselekménnyel elérni kívánt haszonhoz képest, nem követi el a bűncselekményt. „A szituációs bűnmegelőzés »alapfilozófiája«, hogy a bűnözés visszaszorítása elsősorban bűnalkalmak csökkentésén keresztül érhető el."8 A közlekedési bűncselekmények döntő többsége (a balesetokozás mindenképpen) gondatlan cselekmény, így a költség-haszon elemzés kizárólag a balesethez vezető szabályszegés tekintetében értelmezhető. A járművezető reménybeli haszonként könyveli el, hogy ha tudatosan megszegi a szabályt, hamarabb ér céljához. Ennek megvalósítása során azonban jelentősen növeli a baleset bekövetkezésének esélyét, illetve a szabályszegés miatti felelősségre vonástól is tarthat, ami viszont költségként jelentkezik. A felelősségtudat kialakításában a hatósági ellenőrzés keretében kiemelkedő a rendőrség szerepe.

A következő fejezetekben tekintsük át a szabályszegő magatartások hátterében meghúzódó, pszichológiai folyamatokkal magyarázható okokat. A demográfiai tényezőkön (életkor, nem) túl bizonyos személyiségjegyeknek jelentős hatása van a viselkedésre.

6 Christian Weicht: Kriminalprävention aus Sicht der Polizei - eine Aufgabe auch für Architekten und Stadtplaner? Die Kriminalprävention, 6. (2002), 1. 4-11.

7 Ronald V. Clark: Situational Crime Prevention. In Michael Tonry - David P. Farrington (szerk.): Building a Safer Society. Strategic Approach to Crime Prevention. Chicago-London, The University of Chicago Press, 1995. 91-150.

8 Irk Ferenc: Szituációs bűnmegelőzés lakóövezetekben. In Barabás Tünde (szerk.): Épített környezet - bünözés szituációs bünmegelőzés. Budapest, Országos Kriminológiai Intézet, 2008. 78-106. 


\section{2. Életkor}

Az életkor az egyik olyan demográfiai változó, amely kapcsolatban áll a kockázatos magatartással. A fiatalabb gépjármúvezetők gyakrabban sértik meg a közlekedési szabályokat, mint az idősebb vezetők, és gyakrabban ütköznek, szenvednek végzetes közúti balesetet. ${ }^{9}$ Noha a fiatal gépjárművezetők túlreprezentáltak, mégis nagyobb veszélynek vannak kitéve az utakon, mint más életkorúak. ${ }^{10}$ Közlekedési helyzetekben kiütközik tapasztalatlanságuk, a rutin hiánya, amihez hozzájön még a kockázatvállalási hajlandóságuk magasabb foka is. ${ }^{11}$

$\mathrm{Az}$ idősebb gépjárművezetők balesetokozásáról megoszlanak a vélemények. Egyesek szerint a halálos közúti balesetek száma az életkorral csökken, viszont 75 év felett emelkedik a tendencia. Az idősek elsősorban kereszteződésekben, míg a fiatalok vagy egyenes útszakaszon vagy kanyarokban ütköztek. ${ }^{12}$ Korábbi vizsgálatok ezt már a 65. életévtől észlelték. ${ }^{13}$ Ebben szerepet játszhat az a tény, hogy manapság az életminőség javulásával az idősebb gépjárművezetők száma jelentősebb.

Más kutatók vizsgálati eredményei azt mutatták, hogy már a 60. életévüket betöltöttek többet ütköznek, s ez kiváltképp kognitív, motoros és/vagy perceptuális jellemzőkre vezethetô vissza, ${ }^{14}$ továbbá esetükben szociális normák felé fordulást, folyamatos teljesítménycsökkenést jeleztek. ${ }^{15}$

Mégsem csupán az életkor a magyarázat. ${ }^{16} \mathrm{Az}$ olyan súlyosabb funkcióvesztések, mint a demencia, stroke, látásromlás, sokkal balesetveszélyesebbnek bizonyulnak. ${ }^{17}$

\section{Nemek közti különbség}

A demográfiai faktorok és a vezetési stílus kapcsolatát vizsgáló kutatások azt mutatják, hogy a jármúvezető neme szignifikánsan előre jelzi a balesetbe keveredés valószínűségét. A férfiak közlekedési balesetben való részvétele kétszerese a nők részvételének. Egy nő arra irányuló esélye, hogy közúti baleset következtében megsérül,

9 Dana Yagil: Gender and Age-Related Differences in Attitudes toward Traffic Laws and Traffic Violations. Transportation Research Part F: Traffic Psychology and Behaviour, 1. (1998), 2. 123-135.

10 Hőgye-Nagy Ágnes: A biztonságos közúti viselkedést befolyásoló tényezők közlekedés biztonsági kultúrájának vizsgálata, módszertani megfontolásai. Doktori értekezés. Debrecen, Debreceni Egyetem, 2016.

11 David D. Clarke et al.: Work-Related Road Traffic Collisions in the UK. Accident Analysis and Prevention, 41. (2009), 2. 345-351.

12 Gerald Jr. McGwin - David B. Brown: Characteristics of Traffic Crashes among Young, Middle-Aged, and Older Drivers. Accident Analysis and Prevention, 31. (1999), 3. 181-198.

13 Dianne Parker et al.: Intention to Commit Driving Violations: An Application of the Theory of Planned Behavior. Journal of Applied Psychology, 77. (1992), 1. 94-101.

14 John Groeger: Understanding Driving. East Sussex, Psychology Press Ltd., 2000.

15 Brigit Bukasa - R. Kisser - Ulrike Wenninger: Computergestützte Leistungsdiagnostik bei verkehrspsychologischen Eignungsuntersuchungen. Diagnostica Band, 36. (1990), 2/2. 148-165.

16 James McKnight - Scott McKnight: Multivariate Analysis of Age-Related Driver Ability and Performance Deficits. Accident Analysis and Prevention, 31. (1999), 5. 445-454.

17 Mary K. Janke: Accidents, Mileage, and the Exaggeration of Risk. Accident Analysis and Prevention, 23. (1991), 23. 183-188. 
25\%-kal alacsonyabb, mint egy férfié. ${ }^{18}$ Más kutatások szerint a férfiak gyakrabban szenvednek el közúti balesetet a közlekedési szabályok megszegése miatt. Ahol a férfiak gyakrabban szenvedtek balesetet, mint a nők, azt gyorshajtás és ittas vezetés okozta, míg a nők esetén a baleset inkább a közlekedési helyzet megítélésének hibája miatt történt. Harre és munkatársai úgy vélik, inkább a férfiak mutatnak veszélyes vezetési magatartást (ittas vezetés, gyorshajtás), mint a nők..$^{19}$

A balesettel való érintettség a fiatal férfiaknál a legvalószínúbb. ${ }^{20} \mathrm{~A}$ kockázatos vezetést, az agresszív vezetést, a közlekedési szabályok megszegését, és még a rokkant személyeknek fenntartott parkolóhelyek illegális használatát illetően a fiatal férfi vezetőket magas kockázati csoportnak tartják. ${ }^{21}$ Ahogy a fiatalok, úgy a férfiak is felülreprezentáltak a halálos közlekedési balesetek statisztikáiban. ${ }^{22} \mathrm{~A}$ nők körében pedig a fiatalabbak veszélyeztetettebbek..$^{23}$

A maszkulinitás az agresszív vezetési stílusban túnik fel, amely leginkább kiabálásban, szitkozódásban, mutogatásban nyilvánul meg. ${ }^{24} \mathrm{~A}$ férfiak több szándékos szabályszegést követnek el. ${ }^{25}$ Alkohol- vagy kábítószer-fogyasztás után is volán mögé ülnek. ${ }^{26}$

A nőknél a stressz és a depresszió bizonyul rizikófaktornak, ami kapcsolatba hozható a kockázatvállaló vezetési stílussal és a baleseti involváltsággal. ${ }^{27}$

\section{Kockázatvállalás}

Tévedés azt hinni, hogy az embertől a rizikóvállalás idegen lenne, de hogy ki milyen kockázatot vállal, abban jelentős eltérések mutatkoznak. A szenzoros élménykeresés magasabb szintû̉ kockázatvállalási hajlandóságot és kockázatosabb viselkedést

18 Yagil (1998): i. m.

19 Yagil (1998): i. m.

20 Jeffrey Arnett: Drunk Driving, Sensation Seeking, and Egocentrism among Adolescents. Personality and Individual Differences, 11. (1990), 6. 541-546.

21 Hőgye-Nagy (2016): i. m.

22 Annette Dobson et al.: Women Drivers' Behaviour, Socio-Demographic Characteristics and Accidents. Accident Analysis and Prevention, 31. (1999), 5. 525-535; Susan A. Ferguson - Eric R. Teoh - Anne T. McCartt: Progress in Teenage Crash Risk during the Last Decade. Journal of Safety Research, 38. (2007), 2. 137-145.

23 Hong Sok Kim - Hyung Jin Kim - Bongsoo Son: Factors Associated with Automobile Accidents and Survival. Accident Analysis and Prevention, 38. (2006), 5. 981-987.

24 Christine M. Wickens et al.: Does Gender Moderate the Relationship between Driver Aggression and Its Risk Factors? Accident Analysis and Prevention, 45. (2012), 10-18.

25 Türker Özkan - Timo Lajunen: Why Are There Sex Differences in Risky Driving? The Relationship between Sex and Gender-Role on Aggressive Driving, Traffic Offences, and Accident Involvement among Young Turkish Drivers. Aggressive Behavior, 31. (2005), 6. 547-558.

26 Robert E. Mann et al.: Self-Reported Collision Risk Associated with Cannabis Use and Driving after Cannabis Use among Ontario Adults. Traffic Injury Prevention, 11. (2010), 2. 115-122.

27 Wickens et al. (2012): i. m. 
eredményezhet. Inkább a férfiakra jellemző ez a sajátosság, ${ }^{28}$ ami fóként 20 éves korig magas szintű. ${ }^{29} \mathrm{~A}$ fiatalok vakmerőbbnek bizonyulnak.

Akik magasabbra értékelik a saját járművezetői készségeiket, hajlamosak kockázatvállalóbban vezetni. ${ }^{30}$ Vannak, akik a képességeikre koncentrálnak, és megbíznak a saját jármúkezelési tudásukban, mások a biztonságos vezetést tartják szem előtt. Hogy ki, milyen kockázatot vállal, abban számos tényező játszik szerepet.

A magas társasági kockázatvállalóknál erős a dominanciára törekvés, a magabiztosság és impulzivitás, magas fokú expresszivitás, illetve gondatlanság. ${ }^{31}$ Ezenkívül a társas alkalmazkodás mértéke csökkent, ami kifejezett érzelmi keménységgel (darabosság, durvaság) és félelemnélküliséggel párosul. ${ }^{32}$ Ezzel szemben az erős szociális kockázatvállalók nyitottak az új információk iránt, felszabadultak és intellektuálisan rugalmasak. Erős önfegyelem és következetesség birtokában vannak. ${ }^{33}$

$\mathrm{Az}$ anyagi kockázatvállalási hajlam és magas dominancia, akaratérvényesítési törekvések, valamint a csökkent normakövetés között kapcsolat mutatható ki, csakúgy, mint ahogy kimutatható a korreláció az alacsony társas alkalmazkodással is. ${ }^{34}$

\section{Agresszió}

Alapvetően háromféle agressziótípus létezik: a fenyegető (például a bankrabló fegyverrel követeli a pénzt, de nem lő), a kapcsolati (például egy gyermek árulkodik a tanítónak) és a fizikai (például gyilkosság, testi sértés). E három típusnak különböző formáit különítjük el. ${ }^{35}$

Az agresszió egyrészt lehet proszociális (másokért folytatott agresszív cselekvés), másrészt semleges (például bokszmérkőzés közben), illetve antiszociális (mások ellen irányuló agresszív cselekvés). Az antiszociális agresszió lehet továbbá reaktív vagy proaktív. A reaktív agressziót mindig valamilyen, akár képzeletbeli provokáció váltja ki. Erős érzelmek és stresszválasz jellemzi, például magas kortizol- és adrenalinszint. A proaktív agresszió a reaktív ellentéte, megtervezett, kezdeményező formájú agresszió, amely során a stresszhormonszint minimális. Antiszociális agressziónak minősülnek a pszichotikus állapotban elkövetett agressziós cselekedetek is. Ilyenek akkor fordulnak elő, amikor valaki elszakad a valóságtól, és hallucinációi vannak, amelyek gyakran mentális zavarokkal is társulnak.

\footnotetext{
28 Marvin Zuckerman - D. Michael Kuhlman: Personality and Risk-Taking: Common Biosocial Factors. Journal of Personality, 68. (2000), 6. 999-1029.

29 Arnett (1990): i. m.

30 Timo Lajunen - Heikki Summala: Can we Trust Self-Reports of Driving? Effects of Impression Management on Driver Behavior Questionnaire Responses. Transportation Research Part F: Traffic Psychology and Behaviour, 6. (2003), 2. 97-107.

31 Bukasa-Kisser-Wenninger (1990): i. m.

32 Ulrike Wenninger Krupan C.: ART2020 Teszt eljárás. Kézikönyv. Kuratorium für Verkehrssicherheit, 2003.

33 Wenninger-Krupan (2003): i. m.

4 Bukasa-Kisser-Wenninger (1990): i. m.

35 Haller József: Miért agresszív az ember? Budapest, Osiris, 2005.
} 
A járművezető viselkedésének három különböző aspektusát nevezték agreszszívnek a kutatók: ${ }^{36}$ fizikai, verbális vagy gesztikulált agresszió szándékos cselekedeteit (mint például megüt egy másik közlekedőt, szitkozódik vagy obszcén mozdulatot tesz), negatív érzelmeket vezetés közben (például közúti düh) és a kockázatvállalást (például tilos jelzésen áthaladva vagy gyorsan sávot váltva).

\section{Antiszociális személyiségzavar}

$\mathrm{Az}$ agresszió esetében fontos figyelembe venni az agresszió ár-érték arányát, mert az egyénnek az éri meg, ha több haszna származik belóle, mint vesztesége, vagyis az ár-érték arány pozitív. Az agresszió abnormális változata akkor fordul elő, amikor nem származik semmilyen előny az agresszív viselkedésből. Tehát amenynyiben az agresszió nem szolgálja azt a célt, amire használatos, diszfunkcionális, mivel mentális zavarral társul.

$\mathrm{Az}$ antiszociális személyiségzavar jellemzője a lelkiismeret és a mások iránti felelősségérzet hiánya. A társadalmi normák durva megszegése általában már gyerekkorban elkezdődik. Ez az erőszakosság egészen a másokra tekintettel nem lévő viselkedésig fajulhat. Szintén gyakori jel a megrögzött hazudozás vagy lopás. Annak ellenére, hogy gyakran kerülnek bajba, mégsem éreznek szorongást, szégyent vagy bármilyen más, erőteljes negatív érzést. A kriminális mintázatot mutató személyeket szokás pszichopatának vagy szociopatának nevezni, azonban ezek a kifejezések nem szerepelnek a DSM 5-ben. Egyesek közülük egészen elbűvölő emberek lehetnek, akik megtanulták lehengerló stílusukkal kivívni a bizalmat. Emiatt fordul elő, hogy sokáig le sem lepleződnek, amikor pedig mégis, sokszor ügyesen kihátrálnak. A háttérben meghúzódó biológiai okok közé tartozik az amigdala és a szemek feletti agykérgi területek nem megfelelő müködése.

\section{7. Önkontroll}

A magas agresszív interakciós értékeket mutató járművezetőknél szignifikánsan alacsony önkontrollt, korlátozott öntudatosságot, kis mértékủ normakövetést és magas belső feszültséget találtak. ${ }^{37} \mathrm{Az}$ önkontroll jelzi az impulzivitás hiányát, az alacsony szintû spontaneitást, tehát a kontrollt, a szervezettséghez, pontossághoz és módszerességhez való kapcsolatot. A büntetett előéletủ személyek alacsony frusztrációs

36 Chris S. Dula - Mary E. Ballard: Development and Evaluation of a Measure of Dangerous, Aggressive, Negative Emotional, and Risky Driving. Journal of Applied Social Psychology, 33. (2003), 2. 263-282.

37 Bukasa-Kisser-Wenninger (1990): i. m. 
toleranciája és stresszel való megküzdéseinek nehézségei, alacsony szintủ önkontrollja gondot jelenthet a közlekedésben. ${ }^{38}$

Magas értékek erős tudatosságot (lelkiismeretességet), szabálybelátást és megbízhatóságot vonnak maguk után. Gyengébb az érzelmi kapcsolat az autóval és annak vezetésével. Az alkalmas, illetve időkorlátos minősítésű gépjármúvezetôknek jelentősen magasabb önkontrollja van, mint az alkalmatlanoknak. ${ }^{39}$

\section{Társas felelősségtudat}

A vezetési viselkedés normáit társas normaként értelmezhetjük, azaz a közlekedésben részt vevők döntő többsége egyetértéssel fogadja azokat, mintegy megegyezést mutatva a normakövetés területén. A szabálybetartást megelőzi az internalizáció. Ugyanakkor a normasértések növelik a negatív események kockázatát. ${ }^{40}$ Az internalizáció azonban veszélyes is lehet, hiszen nem csupán a szabálykövetésnél, hanem a szankció nélkül maradó szabályszegések esetében is érvényesül.

A közlekedésben elkülönítünk törvényileg szabályozott formális (például „Állj! Elsőbbségadás kötelező" jelzőtáblánál történő megállás) és a közösség által szabályozott informális szabályokat (például ha a szembejövő autós egy kerékpárost előz, lehúzódunk annak érdekében, hogy az elférjen). ${ }^{41} \mathrm{~A}$ társas felelősségtudat inkább ez utóbbi körnél jut szerephez, hiszen a konkrét - általában tilalmakat meghatározó - szabályok megszegése esetén a szankciótól való félelem is jelentős mértékben érvényesül.

Érdemes megfigyelni, hogy a bűnöző életmódot folytató, a társadalmi normákkal általában szembe helyezkedő egyéneknél a közlekedési deviancia is gyakoribb. A börtönbüntetésüket letöltőknél normáktól eltérő, deviáns viselkedést tapasztaltak, 19 és félszer nagyobb valószínűséggel voltak halálos kimenetelű balesetek részesei. ${ }^{42}$

\footnotetext{
38 Hérincs Magdolna: Pszichológiai tesztekben használt bemutatkozási stratégiák vizsgálata. Összehasonlító vizsgálat közlekedés-specifikus (VPT.2 Közlekedési Stílus Teszt) és egy átfogó személyiségteszt (CPI California Psychological Inventory) között. Budapest, 2008.

39 Wenninger-Krupan (2003): i. m.

40 Hőgye-Nagy (2016): i. m.

41 Gunilla M. Björklund - Lars Åberg: Driver Behaviour in Intersections: Formal and Informal Traffic Rules. Transportation Research Part F Traffic Psychology and Behaviour, 8. (2005), 3. 239-253.

42. Hőgye-Nagy (2016): i. m.
} 


\section{Az erkölcsi gondolkodás}

Piaget vizsgálatának ${ }^{43}$ fókuszába a gyermeki gondolkodás fejlődése, valamint az erkölcsi ítéletalkotás került, amely kiterjedt az erkölcsi szabályok és társadalmi konvenciók kialakulására is.

Kohlberg munkássága kiterjedt a serdülő- és felnőttkorra is. Erkölcsi dilemmákat tartalmazó történetekre adott válaszokat elemzett. Az egyikben például az állt, hogy „egy férfi, aki haldokló felesége számára gyógyszert akar szerezni, de nincs elegendő pénze, alkudozik a gyógyszerésszel, hogy adja a gyógyszert olcsóbban. Amikor a gyógyszerész az ajánlatot visszautasítja, a férfi úgy dönt, hogy ellopja a gyógyszert". ${ }^{44}$ Nem a cselekedet jónak vagy rossznak való megítélése, hanem a döntés indoklása alapján az alábbi egyetemes szakaszokat különíthetjük el: ${ }^{45}$

\section{I. szint Prekonvencionális erkölcs}

1. szakasz Büntetésorientáció (szabályok követése a büntetés elkerülése érdekében)

2. szakasz Jutalomorientáció (alkalmazkodás a jutalom és a jóindulat elnyerése érdekében)

II. szint Konvencionális erkölcs

3. szakasz Derékgyerek-orientációs (alkalmazkodás mások helytelenítésének elkerülése érdekében)

4. szakasz Tekintélyorientáció (a törvények és társas szabályok betartása annak érdekében, hogy elkerülje a tekintélyek helytelenítését, valamint az abból eredő bűntudatot, hogy „nem teljesíti kötelességét")

III. szint Posztkonvencionális erkölcs

5. szakasz Társadalmiszerződés-orientáció (az általánosan elfogadott, a köz jóléte szempontjából lényeges elvek által vezérelt cselekvés, és ezen elvek követése, hogy megőrizze a társak tiszteletét és ezáltal az önbecsülését)

6. szakasz Etikaelv-orientáció (saját választású etikai elvek - általában az igazságosság, méltóság és egyenlőség értékei - által vezérelt cselekvés és ezen elvek követése az önvád elkerülése érdekében)

Tízéves korunkig a prekonvencionális szinten vagyunk. Idesorolható az a válasz, amely szerint a férfi jogosan lopta el a gyógyszert, hiszen „ha hagyja, hogy a felesége meghaljon, akkor bajba kerülhet”; „ha valaki lop, akkor elkapják és börtönbe csukják". A szereplő cselekedete mindkét esetben valamilyen várható büntetés miatt minősül jónak vagy rossznak. A konvencionális szinten a legtöbb kamasz más emberek véleményének tükrében értékel. Akik viszont már elérték az absztrakt gondolkodásra való képességet, elsajátították a posztkonvencionális erkölcsöt.

„A társadalmi törvények szerint ő cselekedett helytelenül, a természet vagy Isten törvényei szerint viszont a gyógyszerész, a férfi pedig felmenthető. Az emberi élet

43 Michael Cole - Sheila R. Cole: Fejlődéslélektan. Budapest, Osiris, 2013.

44 Richard C. Atkinson - Ernest Hilgard: Pszichológia. Budapest, Osiris, 2005.

45 Lawrence Kohlberg: Stage and sequence: The cognitive-development approach to socialization. In David A. Goslin (szerk.): Handbook of Socialization Theory and Research. Chicago, Rand McNally, 1969. 347-480. 
minden anyagi haszonnál becsesebb. Még a haldokló személye sem számít igazán. Egy vadidegen embert is kötelességünk megmenteni a haláltól." ${ }^{\prime 6}$

Itt már az etikai elvek megfogalmazása és betartása az önvád elkerülése érdekében történik, amelyet a beszámolók szerint a felnőttek kevesebb mint 10\%-a alkalmaz.

Hozzá kell tenni, hogy több bizonyíték utal arra, hogy az emberek különböző helyzetekben szabályokat alkalmaznak, és kritikaként fogalmazódott meg az is, hogy a szakaszok sorrendje sem egyértelmű. ${ }^{47} \mathrm{Az}$ elméletet továbbá férfiközpontúsága miatt is támadták, ${ }^{48}$ mivel az igazságon és a jogon alapuló férfias, absztrakt gondolkodást magasabb szintre helyezi, mint a gondoskodást és törődést előtérbe helyező nőies gondolkodást.

\section{Jutalmazás és büntetés}

Az egyik legismertebb nevelési modellt megalkotó Bábosik István a jutalmazás és büntetés funkciójának a preferált tevékenység- és magatartásformák gyakorlását, a nemkívánatos magatartásformák és tevékenységek demotiválását tartja. ${ }^{49} \mathrm{~A}$ jutalmazás és büntetés módszerének alkalmazása a társadalmi normák, értékek elérése érdekében történik. Célja a büntető, jutalmazó személy által közvetített értékek megerősítése, valamint az általa elvetettek gyengítése. ${ }^{50}$ Így mind a jutalmazás, mind a büntetés egy nem kívánt viselkedés valószínűségének csökkentésére szolgál.

Nem szabad elfeledkezni azonban a büntetés veszélyeiről sem, hiszen annak számos káros okozata ismert. ${ }^{51}$ Hatása korántsem jósolható meg olyan jól, mint a jutalmazásé, amelynek üzenete az, hogy: „Ismételd meg, amit csináltál”. A büntetés inkább az „Állj!” jelentést hordozza, ugyanakkor nem kínál semmilyen alternatívát. Könnyen előfordulhat, hogy a járművezető a büntetett cselekedetét egy még kevésbé kívánatossal helyettesíti. Ezt az erős visszahatást válthatja ki az igazságtalan büntetés is. Amennyiben a büntetés - a klasszikus kondicionálás elveinek értelmében - a büntető személytől (például rendőrtől), vagy a szituációtól való félelemhez vagy az ezekkel szembeni ellenérzéshez vezethet, akkor nem kívánatos mellékhatásai is lehetnek. Szélsőségesen erős vagy nagyon fájdalmas büntetés ugyanis agresszív viselkedést válthat ki, ami olykor nagyobb problémát okoz, mint maga a büntetni kívánt viselkedés.

46 Kohlberg (1969): i. m. 244, idézi Atkinson-Hilgard (2005): i. m. 110.

47 William Kurtines - Esther B. Greif: The Development of Moral Thought: Review and Evaluation of Kohlberg's Approach. Psychological Bulletin, 81. (1974), 8. 453-470.

48 Carol Gilligan: In A Different Voice: Psychological Theory and Women's Development. Cambridge, Massachusetts, Harvard University Press, 1982. 24-39.

49 Bábosik István: Alkalmazott neveléselmélet. Budapest, OKKER, 2003.

50 Hegedűs Judit: Jutalmazás és büntetés, értékelés és vizsgáztatás. Budapest, Apertus Közalapítvány, 2004.

51 Atkinson-Hilgard (2005): i. m. 
Nincs meg a büntetésnek a kellő eredménye, ha túlzottan enyhe, vagy ha személyesen, hangulatok hatása alatt szabják ki, mert így önkényes jellege van. A jogszabályok betartása az egyén számára hátrányos következményekkel is jár, amelyekre érzékenyebbek vagyunk (például ha megnövekszik a menetidő, akadályozottság érzése), viszont ezek nem veszélyeztetik az emberi életet. Az élet intézményes védelme mellett további cél a jogkövető magatartáshoz kapcsolódó egyéb hátrányos következmények csökkentése. Fontos szempont, hogy a büntetés általában elkerülő aktivitást eredményez és a személyiség valamely részfunkcióját érinti csupán. ${ }^{52} \mathrm{~A}$ megfelelő attitüd kialakításához mélyebb beavatkozásra lehet szükség.

\section{Attitüd}

$\mathrm{Az}$ attitüd olyan pozitív vagy negatív viszonyulás, amely kiterjed a tárgyak, személyek, helyzetek, illetve elvek iránt mutatott vonzalmakra vagy a tőlük való idegenkedésre. Elvont gondolatokat és társadalmi megnyilvánulásokat tartalmaz. Preferenciákat képvisel. Legtöbbször véleményünk megformálásában érhető tetten. Kognitív, affektív (érzelmi) és viselkedéses összevetőkből áll. Nemcsak érzéseket fejez ki, hanem különféle ismeretekhez, az attitüd tárgyára vonatkozó vélekedéshez és az arra vonatkozó cselekedethez kapcsolódik.

Mivel a viselkedés megjóslásához elég az attitűdöket megismerni, az emberek viselkedésének megváltoztatásához először az attitűdjüket kell megváltoztatni. Ez részben megvalósítható a társas befolyásolás módszerével. Az önigazolásra irányuló kutatások szerint például az emberek attitúdje módosul, ha rá lehet venni ôket valamilyen képmutató (az attitűdjeikkel ellentétes) lépésre. ${ }^{53}$

A referenciacsoportok szintén befolyásolhatják attitúdjeinket. Ebben az esetben az attitűdök megváltoztatásának közvetlenebb, a meggyőzésben használt formáinak alkalmazására van szükség, például hirdetésekre, vagy formális és informális nyomásgyakorlás egyéb módjaira. Az attitúd akkor jósolja meg legjobban a viselkedést, ha erős és konzisztens, specifikusan kötődik a megjóslandó viselkedéshez és közvetlen tapasztalaton alapul. Mindez pedig tudatosul az egyénben. Ez utóbbi inkább azokra igaz, akik általában véve is többet foglalkoznak saját gondolataikkal, érzéseikkel, és az adott szituáció következtében kényszerülnek fokozottabb tudatosságra.

Vietnámban, ahol egyébként a közúti balesetek halálozási aránya meghaladja a délkelet-ázsiai országokét, készült egy felmérés, amely a járművezetők attitűdjeiről alkotott véleményekre tér ki. ${ }^{54}$ Elméleti és empirikus szempontokból azt feltételezik,

\footnotetext{
Aranyos Judit - Major Róbert: Kezelő jellegű intézkedés megalkotása a közlekedési bűncselekmények körében. Belügyi Szemle, 4. (2005), 4. 32-52.

53 Atkinson-Hilgard (2005): i. m.

54 Khuat Viet Hung - Le Thu Huyen: Education Influence in Traffic Safety: A Case Study in Vietnam. International Association of Traffic and Safety Sciences Research, 34. (2011), 87-93.
} 
hogy a közlekedési szabályokat sértő viselkedések visszavezethetők a jogszabályokhoz való hozzáállásra.

A vizsgálat eredménye két attitűdre világít rá, az utánzásra és az elkerülési hajlamra.

1. táblázat: Utánzás és az „engedetlenség = nincs kár vagy büntetés” hozzáállás

\begin{tabular}{|l|c|}
\hline Az elmúlt egy hónapban nem büntetett meg a rendőrség. & $82 \%$ \\
\hline Néha én is megszegem a szabályokat. & $72 \%$ \\
\hline $\begin{array}{l}\text { Szinte minden nap látom, hogy az emberek megszegik a közlekedési szabályokat anélkül, hogy } \\
\text { megbüntetnék őket. }\end{array}$ & $71 \%$ \\
\hline A rendőrök gyakran nem büntetik a kerékpárosokat. & $69 \%$ \\
\hline A forgalom jelenlegi állapotában lehetetlen a forgalomszabályok megszegése nélkül vezetni. & $68 \%$ \\
\hline Jelenleg minden közlekedési résztvevő megszegi a közlekedési szabályokat. & $52 \%$ \\
\hline Közlekedési konfliktus esetén a „nagy” járművek hibásak. & $33 \%$ \\
\hline
\end{tabular}

Forrás: Hung-Huyen (2011): i. m.

A szociális tanulás révén az emberek mások viselkedésének és annak következményei alapján tanulnak új válaszokat. Attól függóen fogadunk el vagy utasítunk el egy viselkedést, hogy annak jutalom vagy büntetés a következménye.

2. táblázat: Attitüd: „ha nem szegem meg a törvényt, attól még mások megszegik a törvényt” és „a közlekedési szabályok betartása = kár”

\begin{tabular}{|l|c|}
\hline $\begin{array}{l}\text { Most mindenkinek meg kell próbálnia a saját döntése szerint vezetni, nincs rendezett forgalom } \\
\text { a városban. }\end{array}$ & $85 \%$ \\
\hline Ha torlódás áll fenn, ha engedünk másoknak, akkor azonnal elakadhatunk. & $68 \%$ \\
\hline Rossz sávot kell használnom/rossz helyen kell várakoznom, hogy elkerüljem a torlódást. & $58 \%$ \\
\hline
\end{tabular}

Forrás: Hung-Huyen (2011): i.m.

A menekülő tanulás esetén egy, már folyamatban lévő averzív eseményt kívánunk leállítani, amelyhez negatív érzés társul. Az elkerülő tanulással ezek bekövetkezése elől térünk ki. Például amikor a piros jelzésnél nem hajtunk tovább, nehogy baleset történjen, vagy egy bírságolás után jobban figyelünk a szabályok betartására. Lényegében a félelem visszatartó erő, amely független attól, hogy más miképp vezet.

\section{3. táblázat: Attitüd: „néha érthető a forgalmi előirások megsértése”}

\begin{tabular}{|l|c|}
\hline Időnként érthető, ha nagyobb sebességgel vezet, mint amennyivel szabad. & $64 \%$ \\
\hline Néha érthető, hogy egy kisebb viselkedési szabályszegést követnek el a gyorsabb előrejutás érdekében. & $60 \%$ \\
\hline Néha érthető, hogy áthajt a tilos jelzésen. & $44 \%$ \\
\hline
\end{tabular}

Forrás: Hung-Huyen (2011): i. m. 
A vezető azon döntése, hogy megsérti a szabályt, a hozzáállásától és a szabályok egyedi forgatókönyvének elfogadásától függ. A szabályokhoz való hozzáállás hosszú távú, míg a szabályok elfogadását jobban befolyásolják az adott közlekedési feltételek, amelyekkel a jármúvezetőnek meg kell birkóznia. Fontos tényező még az adott pillanatra jellemző motiváció és a vezetési képesség, észlelési kapacitás nívója.

Ahol a közlekedésbiztonság mutatói rossznak mondhatók, több az agresszív szabályszegés és negatívabb a közlekedésbiztonság iránti attitűd. ${ }^{55} \mathrm{~A}$ gépjárművezetők mégis valahogy azt sajátítják el, hogy a szabályszegések nem feltétlenül vezetnek közúti balesethez, ami igaz is, viszont betartásukat nem a legfontosabbnak tekintik. ${ }^{56}$

\section{2. Összegzés}

A viselkedés a személyiség és a szituációs változók kölcsönhatásának az eredménye. Meghatározó továbbá az attitűdöktől eltérő tényezők szerepe. Az egyik nyilvánvaló faktor a kényszerítő korlátok ereje: gyakran kell oly módon cselekednünk, amely nem áll összhangban azzal, amit érzünk vagy hiszünk. Az azonos korú társak nyomása főleg fiatalabbak esetén lényeges, akikre inkább jellemző a kockázatvállaló vezetési stílus.

A jutalmazás és büntetés alkalmazása az embernek ösztönszerú cselekvése, éppen ezért mindenütt és minden időben, sőt az állatoknál is jelen van. A helytelen tettek kellemetlen, míg a helyesek kellemes érzelmeket váltanak ki. A jutalmazás és büntetés célja, hogy indítékként szolgáljon olyan esetekben, amikor az ember egyébként nem tenné meg azt, amit parancsolnak, vagy nem kerülné el azt, amit tiltanak. Az eredmény attól függ, milyen erős ez az indíték összehasonlítva azzal a vonzóerővel, amellyel a tiltott, vagy azzal a taszítóerővel, amellyel a parancsolt dolog hat.

A büntetés jobban eléri célját, ha egyes szigorúan tiltott cselekedetekre előre meg van állapítva, és a leglényegesebb, hogy azt következetesen végre is hajtják.

A korlátozás akkor hatékony, ha a gátolni kívánt cselekvéshez kapcsolódik, és megelőzi az elkövetendő cselekményt a nem kívánatos tett elkezdése előtt. Amennyiben erre nincs mód, akkor a szankció kiszabása közvetlenül a nem kívánt cselekedetet kövesse. Az elhalasztott büntetés esetén jóval kisebb az eredményes következmény valószínűsége, főként, ha nem derül ki pontosan az ok sem.

Másik fontos tényező a következetesség, tehát az egyszer már büntetett viselkedést a továbbiakban mindig büntetni kell és sosem jutalmazni.

A kultúra szerepét sem hagyhatjuk figyelmen kívül. A személyiségvonásoknak nagyobb befolyásuk van a viselkedés alakítására az individualista kultúrákban, mint

55 Trond Nordfirn et al.: Road Traffic Culture and Personality Traits Related to Traffic Safety in Turkish and Iranian Samples. Safety Science, 44. (2004), 621-628.

56 Stefan Siegrist - Eva Roskova: The Effects of Safety Regulations and Law Enforcement. In Pierre-Emmanuel Barjonet (szerk.): Traffic Psychology Today. Dordrecht, Kluwer Academic Publishers, 2001. 181-206. 
a kollektivistákban. Az ösztönszerűség a kultúra alacsonyabb fokán, míg a magasabb kultúrfokon a tudatosság és bizonyos elvek szerint történő cselekvés érhető tetten.

A büntetés minden olyan esetben, amikor következetesen és közvetlenül a nemkívánatos viselkedés után alkalmazzák, határozottan eredményes lehet, kizárva azt, hogy bárki úgy gondolhatja, kitérhet a büntetés alól, mert rá nem vonatkoznak a szabályok, vagy úgysem fogják tetten érni.

Ahogy a vietnámi kutatás eredményei is igazolják, ez nem feltétlenül magától értetődő, ezért elengedhetetlenné válik a rendőrök szerepe a szabályok betartatásában. Minél inkább törekedni kell arra, hogy csökkenjen a szabálykövető magatartással járó hátrányos következmények valószínúsége, és növelni tudjuk az azzal járó előnyöket.

\section{IRODALOMJEGYZÉK}

Aranyos Judit - Major Róbert: Kezelő jellegű intézkedés megalkotása a közlekedési búncselekmények körében. Belügyi Szemle, 4. (2005), 4. 32-52.

Arnett, Jeffrey: Drunk Driving, Sensation Seeking, and Egocentrism among Adolescents. Personality and Individual Differences, 11. (1990), 6. 541-546. Online: https://doi.org/10.1016/01918869(90)90035-P

Atkinson, Richard C. - Ernest Hilgard: Pszichológia. Budapest, Osiris, 2005.

Bábosik István: Alkalmazott neveléselmélet. Budapest, OKKER, 2003.

Björklund, Gunilla M. - Lars Åberg: Driver Behaviour in Intersections: Formal and Informal Traffic Rules. Transportation Research Part F Traffic Psychology and Behaviour, 8. (2005), 3. 239-253. Online: https://doi.org/10.1016/j.trf.2005.04.006

Bukasa, Brigit - R. Kisser - Ulrike Wenninger: Computergestützte Leistungsdiagnostik bei verkehrspsychologischen Eignungsuntersuchungen. Diagnostica Band, 36. (1990), 2/2. 148-165.

Clarke, David D. - Patrick Ward - Craig Bartle - Wendy Truman: Work-Related Road Traffic Collisions in the UK. Accident Analysis and Prevention, 41. (2009), 2. 345-351. Online: https://doi.org/10.1016/j.aap.2008.12.013

Clark, Ronald V.: Situational crime prevention. In Michael Tonry - David P. Farrington (szerk.): Building a Safer Society. Strategic Approach to Crime Prevention. Chicago-London, The University of Chicago Press, 1995. 91-150.

Cole, Michael- Sheila R. Cole: Fejlődéslélektan. Budapest, Osiris, 2013.

Dobson, Annette - Wendy Brown - Jean Ball - Jennifer Powers - Michael McFadden: Women Drivers' Behaviour, Socio-demographic Characteristics and Accidents. Accident Analysis and Prevention, 31. (1999), 5. 525-535. Online: https://doi.org/10.1016/S0001-4575(99)00009-3

Dula, Chris S. - Mary E. Ballard: Development and Evaluation of a Measure of Dangerous, Aggressive, Negative Emotional, and Risky Driving. Journal of Applied Social Psychology, 33. (2003), 2. 263282. Online: https://doi.org/10.1111/j.1559-1816.2003.tb01896.x

Ferguson, Susan A. - Eric R. Teoh - Anne T. McCartt: Progress in Teenage Crash Risk during the Last Decade. Journal of Safety Research, 38. (2007), 2. 137-145. Online: https://doi.org/10.1016/j. jsr.2007.02.001

Gilligan, Carol: In A Different Voice: Psychological Theory and Women's Development. Cambridge, Massachusetts, Harvard University Press, 1982.

Groeger, John: Understanding Driving. East Sussex, Psychology Press Ltd., 2000. Online: https://doi. org/10.4324/9780203769942 
JUHÁSZ Anikó - MAJOR Róbert: A közúti ellenőrzés pszichikai hatása és a szabályszegő magatartások...

McGwin, Gerald Jr. - David B. Brown: Characteristics of Traffic Crashes among Young, Middle-Aged, and Older Drivers. Accident Analysis and Prevention, 31. (1999), 3. 181-198. Online: https://doi. org/10.1016/S0001-4575(98)00061-X

Haller József: Miért agresszív az ember? Budapest, Osiris, 2005.

Hegedűs Judit: Jutalmazás és büntetés, értékelés és vizsgáztatás. Budapest, Apertus Közalapítvány, 2004.

Hérincs Magdolna: Pszichológiai tesztekben használt bemutatkozási stratégiák vizsgálata. Összehasonlító vizsgálat közlekedés-specifikus (VPT.2 Közlekedési Stílus Teszt) és egy átfogó személyiségteszt (CPI California Psychological Inventory) között. Budapest, 2008.

Hőgye-Nagy Ágnes: A biztonságos közúti viselkedést befolyásoló tényezők közlekedés biztonsági kultúrájának vizsgálata, módszertani megfontolásai. Doktori értekezés. Debrecen, Debreceni Egyetem, 2016. Online: http://hdl.handle.net/2437/229292

Hung, Khuat Viet - Le Thu Huyen: Education Influence in Traffic Safety: A Case Study in Vietnam. International Association of Traffic and Safety Sciences Research, 34. (2011), 87-93. Online: https:// doi.org/10.1016/j.iatssr.2011.01.004

Irk Ferenc: Szituációs bünmegelőzés lakóövezetekben. In Barabás Tünde (szerk.): Épített környezet - bünözés - szituációs bûnmegelőzés. Budapest, OKRI, 2008. 78-106.

Janke, Mary K.: Accidents, Mileage, and the Exaggeration of Risk. Accident Analysis and Prevention, 23. (1991), 2-3. 183-188. Online: https://doi.org/10.1016/0001-4575(91)90048-A

Kim, Hong Sok - Hyung Jin Kim - Bongsoo Son: Factors Associated with Automobile Accidents and Survival. Accident Analysis and Prevention, 38. (2006), 5. 981-987. Online: https://doi.org/10.1016/j.aap.2006.04.001

Kohlberg, Lawrence: Stage and sequence: The cognitive-development approach to socialization. In David A. Goslin (szerk.): Handbook of Socialization Theory and Research. Chicago, Rand McNally, 1969. 347-480.

Kurtines, William - Esther B. Greif: The Development of Moral Thought: Review and Evaluation of Kohlberg's Approach. Psychological Bulletin, 81. (1974), 8. 453-470. Online: https://doi. org/10.1037/h0036879

Lajunen, Timo - Heikki Summala: Can We Trust Self-Reports of Driving? Effects of Impression Management on Driver Behavior Questionnaire Responses. Transportation Research Part F: Traffic Psychology and Behaviour, 6. (2003), 2. 97-107. Online: https://doi.org/10.1016/S1369-8478(03)00008-1

Major Róbert: Rendészet, közlekedésrendészet. In Barabás A. Tünde (szerk.): Tanulmányok Irk Ferenc professzor 70. születésnapjára. Budapest, Országos Kriminológiai Intézet, 2012. 191-210.

Major Róbert: A közlekedésrendészet. In Korinek László (szerk.): Értekezések a rendészetröl. Budapest, Nemzeti Közszolgálati Egyetem, 2014. 227-252.

Mann, Robert E. - Gina Stoduto - Anca Ialomiteanu - Mark Asbridge - Reginald G. Smart - Christine M. Wickens: Self-Reported Collision Risk Associated with Cannabis Use and Driving after Cannabis Use among Ontario Adults. Traffic Injury Prevention, 11. (2010), 2. 115-122. Online: https:// doi.org/10.1080/15389580903536704

McKnight, James - Scott McKnight: Multivariate Analysis of Age-Related Driver Ability and Performance Deficits. Accident Analysis and Prevention, 31. (1999), 5. 445-454. Online: https://doi. org/10.1016/S0001-4575(98)00082-7

Nordffærn, Trond - Özlem Şimşekoğlu - Mohsen Fallah Zavareh - Amin Mohamadi Hezaveh - Amir Reza Mamdoohi - Torbjørn Rundmo: Road Traffic Culture and Personality Traits Related to Traffic Safety in Turkish and Iranian Samples. Safety Science, 66. (2014), 36-46. Online: https://doi.org/10.1016/j.ssci.2014.02.004

Özkan, Türker - Timo Lajunen: Why Are There Sex Differences in Risky Driving? The Relationship between Sex and Gender-Role on Aggressive Driving, Traffic Offences, and Accident Involvement among Young Turkish Drivers. Aggressive Behavior, 31. (2005), 547-558. Online: https://doi. org/10.1002/ab.20062

Parker, Dianne - Antony S. R. Manstead - Stephen G. Stradling - James T. Reason - James S. Baxter: Intention to Commit Driving Violations: An Application of the Theory of Planned Behavior. Journal of Applied Psychology, 77. (1992), 1. 94-101. Online: https://doi.org/10.1037/0021-9010.77.1.94 
Siegrist, Stefan - Eva Roskova: The Effects of Safety Regulations and Law Enforcement. In PierreEmmanuel Barjonet (szerk.): Traffic Psychology Today. Dordrecht, Kluwer Academic Publishers, 2001. 181-206. Online: https://doi.org/10.1007/978-1-4757-6867-1_10

Weicht, Christian: Kriminalprävention aus Sicht der Polizei - eine Aufgabe auch für Architekten und Stadtplaner? Die Kriminalprävention, 6. (2002). 1. 4-11.

Wenninger, Ulrike - C. Krupan: ART2020 Teszt eljárás. Kézikönyv. Fordította: Jávorsky K. Kuratorium für Verkehrssicherheit, 2003.

Wickens, Christine M. - Robert E. Mann - Gina Stoduto - Jennifer E. Butters - Anca Ialomiteanu - Reginald G. Smart: Does Gender Moderate the Relationship Between Driver Aggression and Its Risk Factors? Accident Analysis and Prevention, 45. (2012), 10-18. Online: https://doi.org/10.1016/j. aap.2011.11.013

Yagil, Dana: Gender and Age-Related Differences in Attitudes toward Traffic Laws and Traffic Violations. Transportation Research Part F: Traffic Psychology and Behaviour, 1. (1998), 2. 123-135. Online: https://doi.org/10.1016/S1369-8478(98)00010-2

Zuckerman, Marvin - D. Michael Kuhlman: Personality and Risk-Taking: Common Biosocial Factors. Journal of Personality, 68. (2000), 6. 999-1029. Online: https://doi.org/10.1111/1467-6494.00124

\section{ABSTRACT}

\section{The Psychological Impact of Roadside Checks and the Background to Offensive Traffic Behaviour}

Anikó JUHÁSZ - Major RÓBERT

The basic criteria for traffic safety are law-abiding behaviour. However, for an individual to be able to comply with the rules it is essential for them to believe that the existence of a system of traffic rules is necessary. Socially accepted norms, customs, moral patterns, roles, ethical rules, patterns of behaviour and forms of behaviour conducive to social coexistence are essential for the successful cooperation of society and the maintenance of a democratic order.

Attitudes to rules and legislation are significantly influenced by personal characteristics such as reactions to punishment, and the short- and long-term effects of punishment. In addition to gender differences, the degree of aggression, risk-taking, self-control and social responsibility play a role in the separation of the non-compliant or compliant behaviour. People also differ in the degree of control they can exercise over their emotions. Different levels of moral development imply changing traffic behaviour and even deviance.

The right attitude includes a number of social competencies, in addition to practicing tolerant behaviour. In order to avoid infringement, it is essential to have the ability of self-regulation, autonomy, cooperation and managing problems. In order to increase compliance with following traffic rules, it is necessary to reduce the adverse effects of law-abiding behaviour and increase the likelihood of its beneficial consequences.

Measures related to preventive police action are aimed at improving road safety and preventing accidents. The aim is to ensure that all transport users fully respect the rules.

The present study explores why having the right attitude about following traffic rules is actually necessary, what human factors can be used to explain a traffic infraction causing a road safety risk, and how the penalty affects drivers with different personality traits depending on the situation.

Keywords: traffic psychology, accident prevention, roadside checks, traffic safety, infraction of the law 